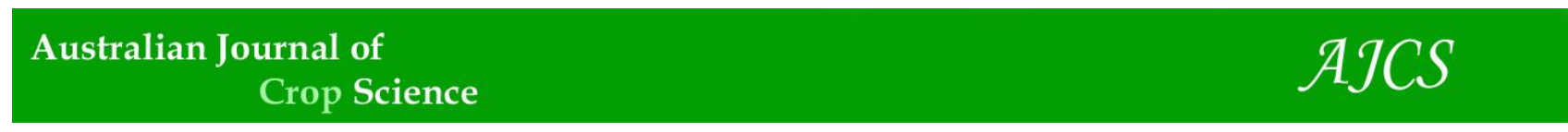

AJCS 12(08):1322-1327 (2018)

ISSN:1835-2707

doi: 10.21475/ajcs.18.12.08.PNE1140

\title{
Inoculation methods and conidial densities of Fusarium oxysporum f. sp. radicis lycoperici in tomato
}

\author{
Alfonso López-Benítez, Sergio A. Rodriguez-Herrera, Odilon Gayosso-Barragán*, Juan Samuel Alcala-Rico, \\ Manuel Vizcarra-López
}

Department of plant breeding, University Autonomous Agrarian Antonio Narro, Saltillo, Coahuila, México

*Corresponding author: gayosso_0188@yahoo.com.mx

\begin{abstract}
Fusarium oxysporum f.sp. radicis-lycopersici (Forl) is one of the most destructive necrotrophic pathogens affecting tomato crops, causing considerable field and greenhouse yield losses. The use of resistant cultivars is a safe, non-contaminating and reliable control method to eradicate or mitigate this disease. However, it is still necessary to determine the best inoculum density, sufficient to induce levels of resistance or susceptibility. In this study, inoculum concentrations of 3,5 and $8 \times 10^{6}$ microconidia per $\mathrm{mL}$ of Forl were evaluated by root immersion and seed spraying in twenty tomato genotypes (Solanum spp.) in a completely randomized design. The germplasm was mainly introduced tomato species from the Genetic Resources Program of the University of California at Davis, USA. The inoculation was done by immersion of roots and by sprinkling of seeds at the time of sowing. For the inoculation by immersion of roots, tomato seedlings of 15 days emergence were used. The wounds were created in root tips then they submerged into the each conidial suspension. Finally, they transplanted into the plastic pots in a greenhouse. Regarding the inoculation by sprinkling of the seed, 20 seeds of each genotype were placed in plastic pots then sprayed with the corresponding conidial suspension. In both cases, the disease index was calculated. This allowed classifying the genotypes as resistant and susceptible. With the root immersion method all the genotypes evaluated showed susceptible. Significant differences were observed $(p \leq 0.01)$ between genetic materials at different inoculum doses with the inoculation of seeds. This allowed classification of genotypes Solanum parviflorum LA 1326, Solanum chesmanii f. minor LA1401, Solanum chmielewskii LA1306, Solanum pimpinellifolium LA722, Solanum pimpinellifolium LA2184 as resistant to Forl with disease index of 3, 4, 5, 8 and 12\% respectively, at a inoculum concentration of $3 \times 10^{6}$ microconidia per $\mathrm{mL}$. These genotypes could be included in a genetic breeding program for resistance to crown and root rot caused by Forl.
\end{abstract}

Keywords: Crown rot, Forl, Immersion of roots, Inoculum density, Resistance.

Abbreviations: FORL_fusarium oxysporum f. sp. radicis lycopersici, PDA_potato dextrose agar, DI_Disease index, ANOVA_analysis of variance, SS_sprinkling the seeds, RI_root immersion.

Introduction

Fusarium oxysporum f. sp. radicis-lycopersici (Forl) is a necrotrophic pathogen. It is a causal agent of crown and root rot tomato, a disease of global economic importance in the cultivation of tomato (Solanum lycopersicum L.) with significant losses in production in greenhouse and in the field (McGovern, 2015). The first reports on Forl came from Japan (1969) and California (1971) (Fazio et al., 1999).

Substantial crop losses in infected fields have given the international attention to disease. The host range of this pathogen comprises at least 36 other species (Menzies et al., 1990). Katan and Katan (1999) identified nine vegetative compatibility groups, indicating high genetic variation within F. oxysporum f. sp. radicis-lycopersici. The disease is characterized by a long period of incubation. The external symptoms appeared immediately, when the infection occurred immediately after sowing. However, if infection occurs during seedling production, the disease may manifest at the time of flowering (Ślusarski, 2000). The pathogen causes root rot and extensive necrotic lesions in the neck and stem base, wilt and plant death. The first symptoms of disease include a yellow discoloration of the older leaves that gradually progresses towards the younger leaves. As the disease progresses, the entire root system becomes brown and the primary root rots (Apodaca et al., 2004). Radicislycopersici constitutes of two special forms. These forms of Fusarium oxysporum are mostly important in tomato cultivation and are likely to coexist simultaneously in the same crop and even in the same plant. However, they present important genetic differences in epidemiology and symptomatology (Çolak and Biçici, 2013). During the evaluation of the evolutionary relationships between special forms associated with tomato, Lievens et al. (2009) found multiple evolutionary lineages for both Fusarium oxysporum f. sp. radicis-lycopersici and F. oxysporum f. sp. lycopersici. The phylogenetic analysis was based on the extension factor of $1 \alpha$ translation and the exopolygalacturonase genes. Although several methods have been used to control this pathogen, the use of resistant cultivars is the most 
acceptable and economical control system (Szczechura et al., 2013). Identification of resistance sources by pathogenicity tests is an essential starting point for obtaining resistant varieties. Some field, greenhouse and laboratory techniques have been generated, including molecular techniques to evaluate tomato germplasm (Morid et al, 2012).

The penetration of the vascular elements of the tomato seedlings roots by Forl depends on the presence of damaged, senescent, necrotic cells or those provide the entrance through wounds. The efficiency of inoculation will increase if roots of seedlings are wounded (Beckman, 1987). Jacobs \& Van Heerden (2012) identified Fusarium oxysporum f. sp. radicis-lycopersici as the causal agent of crown and root rot of tomato in South Africa. They studied morphological and genetic characterization and pathogenicity assays by immersion of root (inoculation) at a concentration of $2 \times 10^{7}$ microconidia per $\mathrm{mL}$ for 3 minutes. Baysal et al. (2009) also inoculated tomato plants for $10 \mathrm{~min}$ in a conidial suspension of Forl of $7 \times 10^{7}$ conidia/mL. They were able to isolate and identify fourteen strains with characteristics of Forl, corroborating their identification through the use of microbiological and molecular markers. Fusarium oxysporum f.sp. radicis-lycopersici (Forl) is one of the most destructive necrotrophic pathogens affecting tomato crops, causing considerable field and greenhouse. The use of resistant cultivars is a safe, non-contaminating and reliable control method to eradicate or mitigate this disease. Prior to this, it is necessary to determine the inoculum density sufficient to induce levels of resistance or susceptibility. In this study, inoculum concentrations 3,5 and $8 \times 10^{6}$ microconidia per $\mathrm{mL}$ of Forl were evaluated by root immersion and seed spraying in twenty tomato genotypes (Solanum spp.) in a completely randomized design.

\section{Results and discussion}

\section{Root immersion inoculation}

All evaluated genetic materials were susceptible to fungi with disease rates higher than $50 \%$ (Table 2). However, some significant differences were observed among the different Solanum materials and among the inoculum doses (Table 3). In the diseased plants, the symptoms began with the appearance of a brown coloration in the root, based on the stem and vascular system that extended from three to six centimeters above the knot of the plant. In some genetic materials, we also observed weak and stunted plants with slight to moderate wilting.

The Walter variety which is a susceptible control showed an average disease rate of $79 \%$. In tomato culture, root cell death occurred rapidly upon protoplast contact with fungal hyphae. This pathogen penetrates the roots mainly through wounds and proceeds into and throughout the vascular system, leading to functional collapse, systemic wilting and often the death of the infected plant (Steinkellner et al., 2005). This suggests that two centimeters damage to the roots by cutting prior to inoculation can facilitate the entry of the pathogen, subsequent invasion and death of the root cells. This usually causes a high severity of the disease.

In the wall of the cells of the cortex of tomato roots, aromatic compounds and suberine are formed as a normal response of resistant plants to the penetration of root pathogens and after facilitating the entry of the fungus into the tissues of roots, the pathogen enters easily (Nawrath et al., 2013). In this study, the method of inoculation of this pathogen with recommended doses of inoculum could not distinguish resistance responses between the studied genotypes.

Three days after inoculation, most of the tomato seedlings had several brown spots along the main root, including the crown. The network of hyphae invaded most of the root surface and spread to the tips, while the cells of the epidermal tissue are completely colonized by hyphae (Lagopodi et al., 2002). This colonization, although discontinuous because the plant's defense reactions limited the spread of the fungus, indicates the possibility that a resistant cultivar could be invaded and attacked when the disease is induced artificially so drastically. Therefore, defense mechanisms such as wall opposition, production of secondary metabolites, lignification and occlusion of vascular tissue and the formation of tylose (Alabouvette et al., 2009) may have lost efficacy to retain away the fungus.

Koyyappurath et al. (2015) employed histopathological preparations. They observed the preparations through wide field and multiphoton microscopy and showed that $F$. oxysporum penetrated the root hair region of roots, and then invaded the cortical cells, where it induced necrosis. The hyphae never invaded the root vascular system up to 9 days post-inoculation.

The response of the genetic materials to root immersion was "high susceptibility" in the three inoculum densities. To prevent evasions of genotypes susceptible to infection, it is common for researchers to use high inoculum densities. In these cases, it is easy to detect a high level of resistance but small differences in susceptibility tend to disappear.

The optimum inoculum density is the one that greatly allows plants to avoid evasion of pathogen. The identification of resistant materials and only the most susceptible genotypes are strongly affected (Elmer, 2002). The inoculum concentration of $3 \times 10^{6}$ conidia per $\mathrm{mL}$ was adequate to induce the disease. This method is efficient to evaluate germplasm of Solanum species for resistance to Fusarium oxysporum f. sp. radicis-lycopersici.

\section{Spray inoculation on seeds}

Spray inoculation on seeds at the time of planting is a method that has been little used in tomato, but is very effective in inducing Fusarium oxysporum diseases (Fazio et al. 1999). In this experiment, the rate of disease was lower than those obtained by inoculation of root immersion. The Walter variety was a susceptible control showed disease rates of 75,75 and $87.5 \%$ for the concentrations of $3 \times 10^{6}$, $5 \times 10^{6}$, and $8 \times 10^{6}$ conidia per $\mathrm{mL}$ of suspension, respectively, with a mean disease index of $79 \%$.

The analysis of variance for disease index indicated significant differences for inoculum doses and between genetic materials (Table 3). The differences enabled distinguishing of genetic materials from completely healthy (with $0 \%$ ) to fully susceptible disease rates to disease rates higher than $50 \%$. For discrimination of susceptible and/to resistant materials, those with an average disease index of 0 to $25 \%$ were considered to be resistant. The moderately susceptible to intermediate plants showed indexes of 26 to $50 \%$. The susceptible plants were those that presented disease rates higher than $50 \%$. 
Table 1. Tomato genotypes (Solanum spp.) evaluated for their reaction to Fusarium oxysporum f. sp. radicis lycopersici by two inoculation methods and three inoculum densities.

\begin{tabular}{|c|c|c|c|}
\hline Cultivars and species & Key PCRG-UC ${ }^{1}$ & $\mathrm{FC}$ & Origin \\
\hline S. lycopersicum cv. Creole & LA404 (90L335) & Red & Perú \\
\hline S. lycopersicum cv. Creole & LA1251 (90L3575) & Red & Ecuador \\
\hline S. lycopersicum cv. Creole & LA1021 (84L6594-1,2) & Red & Ecuador \\
\hline S. lycopersicum cv. Creole & LA468 (83L4649) & Red & Chile \\
\hline S. lycopersicum cv. Creole & LA172 (84L6491-4) & Yellow & Bolivia \\
\hline S. lycopersicum cv. Creole & LA147 (90L3518) & Red & Honduras \\
\hline S. lycopersicum cv. Saladette & LA2662 (88L1368) & Red & EUA \\
\hline S. lycopersicum cv. Edkawi & LA2711 (86L9489) & Red & Egipto \\
\hline S. lycopersicum cv. Walter & & Red & EUA \\
\hline S. lycopersicum cv. $I_{3} R_{3}$ & & Red & EUA \\
\hline S. lycopersicum cv. Bonnie Best & & Red & EUA \\
\hline S. lycopersicum cv. Manapal & & Red & EUA \\
\hline S. pimpinellifolium & LA722 (86L29486) & Red & Perú \\
\hline S. pimpinellifolium & LA2184 (87L0413) & Red & Perú \\
\hline S. chmielewskii & LA1306 (87L0617) & Green & Perú \\
\hline S. chesmanii f. minor & LA1401 (85L8098) & Red & Ecuador \\
\hline S. parviflorum & LA1326 (81L572) & Green & Perú \\
\hline S.lycopersicon var. cerasiforme & LA1673 (83L4805) & Red & Perú \\
\hline S. hirsutum f. glabratum & LA1223 (86L9840) & Green & Ecuador \\
\hline S. chilense & LA1963 (85L1851) & Green & Perú \\
\hline
\end{tabular}

Table 2. Disease index in 20 tomato genotypes (Solanum spp.) inoculated with three inoculum densities of Fusarium oxysporum $\mathrm{f}$. sp. radicis-lycopersici and two methods of inoculation.

\begin{tabular}{|c|c|c|c|c|c|c|c|c|c|}
\hline \multirow[b]{2}{*}{$\begin{array}{l}\text { Solanum spp and key PCGR- UC }{ }^{1} / \\
\text { inoculum density }\end{array}$} & & \multicolumn{3}{|c|}{ RI } & \multicolumn{5}{|c|}{ SS } \\
\hline & & $3^{*}$ & $5^{*}$ & $8^{*}$ & $\begin{array}{l}\text { Mean } \\
\text { value }\end{array}$ & $3 *$ & $5 *$ & $8^{*}$ & $\begin{array}{l}\text { Mean } \\
\text { value }\end{array}$ \\
\hline S. lycopersicum cv. Creole LA404 & 1 & 80 & 82.5 & 82.5 & $82 a b$ & 52.5 & 70 & 75 & $66 a b$ \\
\hline S. lycopersicum cv. Creole LA1251 & 2 & 80 & 80 & 90 & $83 a b$ & 60 & 65 & 65 & $63 a b$ \\
\hline S. lycopersicum cv. Creole LA1021 & 3 & 75 & 87.5 & 90 & $84 a$ & 57.5 & 65 & 65 & $63 a b$ \\
\hline S. lycopersicum cv. Creole LA468 & 4 & 67.5 & 82.5 & 90 & $80 a b c$ & 57.5 & 57.5 & 70 & $62 a b$ \\
\hline S. lycopersicum cv. Creole LA172 & 5 & 67.5 & 80 & 75 & $74 a b c$ & 47.5 & 47.5 & 60 & $52 \mathrm{bcd}$ \\
\hline S. Iycopersicum cv. Creole LA147 & 6 & 67.5 & 82.5 & 90 & $80 a b c$ & 62.5 & 67.5 & 75 & $68 a b$ \\
\hline S. Iycopersicum cv. Saladette LA2662 & 7 & 67.5 & 85 & 85 & $79 a b c$ & 20 & 25 & 25 & $23 \mathrm{e}$ \\
\hline S. lycopersicum cv. Edkawi.LA2711 & 8 & 72.5 & 87.5 & 87.5 & $83 a b$ & 25 & 62.5 & 77.5 & $55 a b c$ \\
\hline S. lycopersicum cv. Walter & 9 & 75 & 75 & 87.5 & 79abc & 75 & 75 & 87.5 & $79 a$ \\
\hline S. lycopersicum Cv. $I_{3} R_{3}$ & 10 & 80 & 70 & 87.5 & $79 a b c$ & 70 & 65 & 75 & $70 a b$ \\
\hline S. lycopersicum cv. Bonnie Best & 11 & 50 & 62.5 & 62.5 & $58 \mathrm{bc}$ & 62.5 & 72.5 & 87.5 & 74ab \\
\hline S. lycopersicum cv. Manapal & 12 & 60 & 67.5 & 67.5 & $65 a b c$ & 57.5 & 57.5 & 85 & $67 a b$ \\
\hline S. pimpinellifolium. LA722 & 13 & 50 & 57.5 & 57.5 & $55 c$ & 7.5 & 7.5 & 10 & $8 \mathrm{e}$ \\
\hline S. pimpinellifolium LA2184 & 14 & 50 & 55 & 87.5 & $64 a b c$ & 5 & 5 & 25 & $12 \mathrm{e}$ \\
\hline S. chmielewskii LA1306 & 15 & 50 & 55 & 62.5 & $56 c$ & 0 & 0 & 15 & $5 e$ \\
\hline S. chesmanii f. minor LA1401 & 16 & 50 & 57.5 & 82.5 & $63 a b c$ & 0 & 0 & 12.5 & $4 e$ \\
\hline S. parviflorum LA 1326 & 17 & 60 & 67.5 & 60 & $63 a b c$ & 5 & 0 & 5 & $3 e$ \\
\hline $\begin{array}{l}\text { S. esculentum cv. Cerasiforme } \\
\text { LA1673 }\end{array}$ & 18 & 80 & 67.5 & 82.5 & $77 a b c$ & 57.5 & 60 & 67.5 & $62 a b$ \\
\hline S. hirsutum f. glabratum LA 1223 & 19 & 50 & 65 & 87.5 & $68 a b c$ & 5 & 27.5 & 45 & 26de \\
\hline S. chilense LA 1963 & 20 & 82.5 & 82.5 & 87.5 & $84 a$ & 20 & 27.5 & 40 & 29 cde \\
\hline
\end{tabular}

${ }^{1}$ Program of conservation of genetic resources, University of California, Davis, Ca., ${ }^{*}=$ Millions conidia per $\mathrm{mL}$ suspensión, RI $=$ Root Immersion, $\mathrm{SS}=$ Spray to seed. Level of significance $=0.01$, Figures followed by different letters are statistically different.

Table 3. Mean squares of the analysis of variance for disease index (DI) and percentage of germination. Inoculation by root immersion (IR) and by sprinkling the seeds at the time of planting (SS).

\begin{tabular}{|c|c|c|c|c|}
\hline \multirow[b]{2}{*}{ Source of variation } & \multicolumn{2}{|c|}{$\mathrm{RI}$} & \multicolumn{2}{|c|}{ SS } \\
\hline & G de $L$ & DI & DI & $\%$ Germination \\
\hline Species of Solanum & 19 & $309.05 * *$ & $2206.68 * *$ & $10.42 * *$ \\
\hline Density of inoculum & 2 & $1034.48 * *$ & $1321.67 * *$ & $59.35 * *$ \\
\hline Error & 38 & 50.27 & 53.57 & 0.66 \\
\hline C. V. & & 9.47 & 16.43 & 23.25 \\
\hline
\end{tabular}




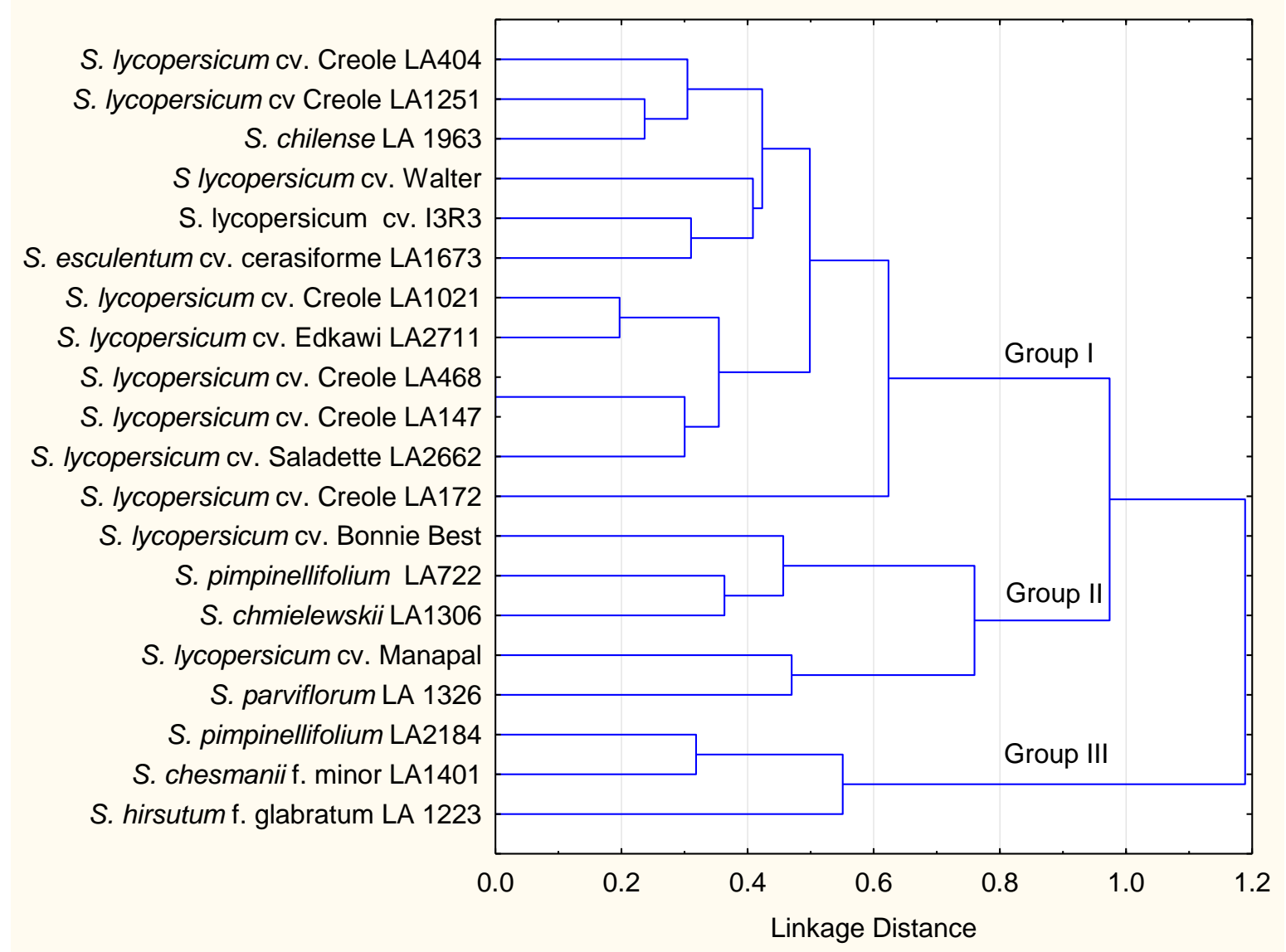

Fig 1. Dendogram of 20 tomato genotypes based on the disease index of Fusarium oxysporum f. sp. radicis lycopersici.

Based on these criteria, Solanum parviflorum LA $1326^{2}$, Solanum chesmanii f. minor LA1401, Solanum chmielewskii LA1306, Solanum pimpinellifolium LA722, Solanum pimpinellifolium $\mathrm{LA}_{2184^{2}}$ and Solanum lycopersicum CV. Saladette LA2662 showed resistance to the fungus Fusarium oxysporum f. sp. radici-lycopersici. For its part, Solanum hirsutum f. glabratum LA 1223 and Solanum chilense LA 19632 showed moderate susceptibility. The other materials were susceptible with disease rates higher to $50 \%$.

The average germination percentage of the seeds in this experiment was low. The analysis of variance indicated highly significant differences $(p \leq 0.01)$ for inoculum doses with germination rates of $44.3 \%, 48.4 \%$ and $48.7 \%$ with inoculum doses of $3 \times 10^{6}, 5 \times 10^{6}$ and $8 \times 10^{6}$ conidia $/ \mathrm{mL}$, respectively. It is possible that the fungus affected seed germination by reducing the percentage of germination regardless of inoculum doses applied. Apodaca et al. (2001) have successfully evaluated the response of tomato cultivars to the inoculation of Fusarium oxysporum $\mathrm{f}$. sp. lycopersici in vitro, pre-inoculating the seeds.

For some soil borne pathogens, it has been observed that an increase in the inoculum population in the soil causes the disease to start earlier and the severity and incidence of the disease to be higher. In this experiment the highest values of disease index were observed, when the highest concentration $\left(8 \times 10^{6}\right)$ was used. However, it was also possible to observe that the $3 \times 10^{6}$ concentration was sufficient to induce the disease in tomato genotypes in greenhouse conditions.
Berbegal et al. (2007) observed that both the incidence and severity of wilt caused by Verticillium dahliae Kleb. in artichoke (Cynara cardunculus L. var. Scolymus (L.) Fiori) increased with increasing inoculum density up to 34 microsclerotia per gram of soil, with an average percentage of infected plants of more than $50 \%$.

Khan et al. (2000) obtained significant correlations between inoculum density and disease severity and incidence in radish (Raphanus sativus L.) plants infected with Verticillium dahliae Kleb. However, they indicated that a prediction, only based on inoculum densities, may not be reliable under field condition when other factors are not under control and affect the inoculum-disease density ratio.

\section{Cluster analysis}

A cluster analysis was carried out considering the disease index value of the twenty genotypes, when inoculated with a density of $3 \times 106$ microconidia per $\mathrm{mL}$ of Forl. The twenty genotypes were classified into three large groups (I, II and III) (Figure 1). In group I, totally susceptible tomato genotypes were located. In group II and III, the tomato genotypes with resistance to Forl, mostly wild tomato species, were located. These genotypes could be included in genetic breeding program for resistance to crown and root rot caused by Forl. The wild species related to the tomato crop possess individual attributes of potential importance for the plant breeding of cultivated varieties by the introduction of important agronomic traits, such as resistance to diseases (Koenig et al., 2013). 


\section{Materials and methods}

\section{Plant materials}

The study germplasm were 20 introductions of tomato species (Solanum spp.) from the genetic resources program of the University of California, Davis, USA (Table 1). Of these, six were cultivar creole from diverse origins, six obsolete commercial cultivars and eight correspond to different species originating in Peru and Ecuador. The Walter cultivar was included as a susceptible control.

\section{Fungal strain used in the experiment}

The strain of Fusarium oxysporum f. sp. radicis-lycopersici, used in this study was isolated from the base of the stem of tomato plants that presented characteristic symptoms of this disease as yellowing of the leaves and sudden wilting during the ripening of the first fruits. For this, stem sections of approximately $3 \mathrm{~mm}$ were disinfected with $1 \%$ sodium hypochlorite solution for 3 minutes, seeded in a potatodextrose-agar (PDA) culture medium in Petri dishes and incubated at $23 \pm 2{ }^{\circ} \mathrm{C}$ for six days. After this time, a tip transfer of hypha was carried out to obtain monosporic cultures. Increases of the pathogen were made and concentrations of 3,5 and $8 \times 10^{6}$ microconidia per $\mathrm{mL}$ were adjusted to perform the corresponding inoculations.

\section{Plant inoculation}

The inoculation was done in two ways, by immersing the root tips in the spore suspensions and by sprinkling the seeds with the suspension of conidia at the time of planting.

\section{Immersion of roots in suspensions of spores}

Seeds of each of the genetic material to be evaluated were seeded in 200 cavities polystyrene trays with sterile soil. Fifteen days after germination twenty seedlings of each genetic material were inoculated with each of the inoculum concentrations used. For this, $2 \mathrm{~cm}$ of the root tips of the seedlings were cut and immersed in each of the suspensions of spores for 2 minutes, after which they were transplanted into $30 \mathrm{~cm}$ diameter plastic pots with sterile forest soil and kept in greenhouse for eight weeks until evaluation (Manzo et al., 2016).

\section{Spray of seeds with the suspension of conidia at the time of planting}

For this purpose, groups of four $30 \mathrm{~cm}$ diameter plastic pots were formed for each of the genetic materials. The pots also contained sterile forest floor. In each pot of the same group, 20 seeds of the same genetic material previously disinfected with $1 \%$ sodium hypochlorite and were placed in spaced form. Each pot was inoculated with three concentrations of inoculum, sprinkling the corresponding microspore suspension on the seeds and then covered with $0.5 \mathrm{~cm}$ layer of the same soil (Shin et al., 2014). The volume of the inoculum suspension was sufficient to cover the seeds completely.

\section{Disease scoring}

The evaluation was done eight weeks after inoculation according to the values of a severity scale where; $0=$ healthy plants; 1 = slight root rot (less than $10 \%$ of the total area); 2 $=$ dark lesions in $25 \%$ of the root; $3=$ infection in the middle of the total area of the root, severe rot in the main root; $4=$ infection in $75 \%$ of the total root area, crown lesions, wilting of older leaves, and $5=$ severe infection in the total root area, wilt and death of young leaves (Çakır et al., 2014). Disease index (DI) was calculated using the following formula:

Disease index

$=\frac{\sum \text { (rating number } \mathrm{x} \text { number of plants in the rating) }}{\text { total number of plants } \mathrm{x} \text { highest rating }} \times 100$

\section{Experimental design and data analysis}

In both experiments, a completely randomized design with factorial arrangement of two factors with two replications was used, where factor A corresponds to Solanum materials and factor $B$ to inoculum concentrations $\left(3,5\right.$ and $8 \times 10^{6}$ microconidia per $\mathrm{mL}$ ). First, an analysis of variance was performed with the values obtained on disease index and a comparison of means by the Tukey test, with a significance level of $p \leq 0.01$.

\section{Cluster analysis}

A cluster analysis was carried out considering the disease index values of the twenty genotypes when inoculated with a density of $3 \times 106$ microconidia per $\mathrm{mL}$ of Forl. The cluster analysis allowed classification of genotypes into resistant and susceptible

\section{Conclusion}

The methods of inoculation by root immersion and seed spray were very efficient to induce the crown and root rot disease caused by Fusarium oxysporum f. sp. radicislycopersici in greenhouse. The highest values of disease index were observed when the concentration of $8 \times 10^{6}$ conidia per $\mathrm{mL}$ was used. However, the $3 \times 10^{6}$ concentration was sufficient to induce the disease with indices greater than $50 \%$. It was possible to identify genotypes resistant to Fusarium oxysporum f. sp. radici-lycopersici, which can be included in subsequent genetic breeding works for resistance to this pathogen.

\section{References}

Alabouvette C, Olivain C, Migheli Q, Steinberg C (2009) Microbiological control of soil-borne phytopathogenic fungi with special emphasis on wilt-inducing Fusarium oxysporum. New Phytol. 184(3):529-544.

Apodaca SMA, Zavaleta ME, Osada KS, García ER, Valenzuela UJR (2001) Comparison of techniques to evaluate in vitro the pathogenicity of Fusarium oxysporum f. sp. radicis lycopersici and effect of temperature. Rev Mex Fitopatol. 19(2):197-202. 
Apodaca SMA, Zavaleta ME, Osada KS, García ER, Valenzuela UJG (2004) Asymptomatic hosts of Fusarium oxysporum Schlechtend. f. sp. radicis-lycopersici W.R. Jarvis y and Shoemaker in Sinaloa, México. Rev Mex Fitopatol. 22(1):713.

Baysal O, Siragusab M, Iktena H, Polata I, Gumrukcua E, Yigitc F, Carimib F, Teixeira da Silva JA (2009) Fusarium oxysporum f. sp. lycopersici races and their genetic discrimination by molecular markers in west Mediterranean region of Turkey. Physiol Mol Plant Pathol. 74(1):68-75.

Berbegal M, Ortega A, Garcia JJ, Armengol J (2007) Inoculum density disease development relationship in Verticillium wilt of artichoke caused by Verticillium dahliae. Plant Dis. 91(9):1131-1136.

Beckman CH, Verdier PA, Mueller WC (1989) A system of defense in depth provided by vascular parenchyma cells of tomato in response to vascular infection with Fusarium oxysporum f. sp. lycopersici race 1. Physiol Mol Plant Pathol. 34(3):227-239.

Çakır B, Gül A, Yolageldi L, Özaktan H (2014) Response to Fusarium oxysporum f. sp. radicis-lycopersici in tomato roots involves regulation of SA and ET responsive gene expressions. Eur J Plant Pathol. 139(2):379-391.

Colak A, Biçici M (2013) PCR detection of Fusarium oxysporum f. sp. radicis-lycopersici and races of $F$. oxysporum f. sp. lycopersici of tomato in protected tomato growing areas of the eastern mediterranean region of Turkey. Turk J Agric For. 37: 457-467.

Elmer WH (2002) Influence of inoculum density of Fusarium oxysporum f. sp. cyclaminis and sodium chloride on cyclamen and the development of Fusarium wilt. Plant Dis. 86:389-393.

Fazio G, Stevens MR, Scott JW (1999) Identification of rapd markers linked to Fusarium crown and root rot resistance (Frl) in tomato. Euphytica 105(3):205-210.

Jacobs A, Van Heerden SW (2012) First report of Fusarium oxysporum f. sp. radicis-lycopersici in South Africa. Australas Plant Dis Notes 7(1):29-32.

Katan T, Katan J (1999) Vegetative compatibility in Fusarium oxysporum f.sp. radicis-lycopersici from the UK, the Netherlands, Belgium and France. Plant Pathol. 48(4): 541549

Khan A, Atibalantia N, Eastburn DM (2000) Influence of inoculum density of Verticillium dahliae on root discoloration of horseradish. Plant Dis. 84(3):309-315.

Koenig D, Jiménez JM, Kimura $S$, Fulop $D$, Chitwood DH, Headland LR, CKumar R, Covington MF, Kumar U, An VT, Tohge T, Bolger A, Schneeberger K, Ossowski S, Lanz C, Xiong G, Taylor-Teeples M, Brady SM, Pauly M, Weigel D, Usadel B, Fernie AR, Peng J, Sinha NR, Maloof JN (2013) Comparative transcriptomics reveals patterns of selection in domesticated and wild tomato. Proc Natl Acad Sci USA. 110(28):655-662.
Koyyappurath S, Atuahiva T, Le Guen R, Batina H, Le Squin S, Gautheron N, Edel HV, Peribe J, Jahiel M, Steinberg C, Liew ECY, Alabouvette C, Besse P, Dron M, Sache I, Laval V, Grisoni M (2015) Fusarium oxysporum f. sp. radicis-vanillae is the causal agent of root and stem rot of vanilla. Plant Pathol. 65(4):612-625.

Manzo D, Ferriello F, Puopolo G, Zoina A, Esposito D, Tardella L, Ferrarini A, Ercolano MR (2016) Fusarium oxysporum f.sp. radicis lycopersici induces distinct transcriptome reprogramming in resistant and susceptible isogenic tomato lines. BMC Plant Biol. 16:53.

McGovern RJ (2015) Management of tomato diseases caused by Fusarium oxysporum. Crop Prot. 73:78-92.

Menzies JG, Koch C, Seywerd F (1990) Additions to the host range of Fusarium oxysporum f. sp.radicis-lycopersici. Plant Dis. 74: 569-572.

Morid B, Hajmansoor S, Kakvan N (2012) Screening of resistance genes to fusarium root rot and fusarium wilt diseases in tomato (Lycopersicon esculentum) cultivars using RAPD and CAPs markers. Euro J Exp Bio. 2(4):931939.

Nawratha C, Schreiber L, Frankeb RB, Geldner N, Reina-Pinto JJ, Kunst L (2013) Apoplastic diffusion barriers in Arabidopsis. Arabidopsis Book 11:e0167.

Lagopodi LA, Ram FJA, Lamers EMG, Punt JP, Van den Hondel AMJJC, Lugtenberg JJB, Bloemberg VG (2002) Novel aspects of tomato root colonization and infection by Fusarium oxysporum f. sp. radicis-lycopersici revealed by confocal laser scanning microscopic analysis using the green fluorescent protein as a marker. Mol Plant Microbe Interact. 15(2):172-179.

Lievens B, Peter VB, Christel V, Stefan VK, Martijn R, Bart T (2009) Evolutionary relationships between Fusarium oxysporum f. sp. lycopersici and F. oxysporum f. sp. radicislycopersici isolates inferred from mating type, elongation factor-1alpha and exopolygalacturonase sequences. Mycol Res. 113:1181-1191.

Shin S, Kim KH, Kang CS, Cho KM, Park CS, Okagaki R, Park JC (2014) A simple method for the assessment of Fusarium head blight resistance in Korean wheat seedlings inoculated with Fusarium graminearum. Plant Pathol J. 30(1):25-32.

Slusarski C (2000) Choroby odglebowe pomidorów (cz. II). W bezglebowej uprawie pod oslonami. Haslo Ogrodnicze 2: 46-49.

Steinkellner S, Mammerler R, Vierheilig H (2005) Microconidia germination of the tomato pathogen Fusarium oxysporum in the presence of root exudates. J Plant Interact. 1(1): 23-30.

Szczechura W, Staniaszek M, Habdas H (2013) Fusarium oxysporum f. sp. radices-lycopersici the cause of fusarium crown and root rot in tomato cultivation. J Plant Prot Res. 53:2-6.

Szczechura W, Staniaszek M, Habdas H (2013) Fusarium oxysporum f. sp. radicis-lycopersici the cause of Fusarium crown and root rot in tomato cultivation. J Plant Prot Res. 53(2):172-175. 